\title{
Effect of Atrazine, Fertilizer, and 2,4-D on Winter Grazing Preferences of Beef Cows on Northcentral Oklahoma Tallgrass Prairie
}

\author{
R.L. BAKER AND JEFF POWELL
}

\section{Abstract}

A good condition, tallgrass prairie experimental area was treated with selected combinations of atrazine, 2,4-D, and NPK fertilizer in spring 1975 and 1976. Crude protein contents in November herbage ranged from $3.4 \%$ to $6.3 \%$ in treated samples. Untreated herbage contained $5.0 \%$ crude protein. Nonlactating beef cows were allowed to graze freely on the area during December, 1976. Utilization of herbage ranged from $43 \%$ to $87 \%$. Utilization was greatest on NPK areas (82\%), $3.4 \mathrm{~kg}$ atrazine + NP areas $(85 \%)$, and $3.4 \mathrm{~kg}$ atrazine + NPK areas $(87 \%)$. Decreaser species comprised a larger percentage of the total production on atrazine + NP, atrazine + NPK, and 2,4-D + NPK areas than on fertilizer-only areas. Tallgrass prairie treated with atrazine and fertilizer or 2,4-D and fertilizer was preferred by beef cows as winter forage over untreated herbage. There was a $15 \%$ increase in herbage utilization for every $1 \%$ increase in crude protein in the herbage in December.

Herbicides and fertilizers are effective forage improvement tools when combined with a sound management plan. However, ranchers are often forced to supply a supplemental protein source to maintain animals and effectively use available forage when grazing an area in winter (Shepherd and Hughes 1970).

The ideal winter forage should supply proper protein and energy needs. Various combinations of fertilizers and herbicides increase forage quality and production during the growing season (Duncan and Hylton 1970, Kay and Torell 1970, Houston and van der Sluijs 1975). However, after plant maturity, crude protein content is at or below animal maintenance levels (Baker et al. 1980).

Little quantitative data has been published relating animal preference for fertilized and herbicide-treated areas, but these chemicals can influence livestock preference (Green et al. 1958, Smith and Lang 1958, Shaw and Dodd 1979). Plant hormone metabolism is influenced by triazine herbicides, and growth stimulations affect the entire morphological structure of the plant (Ebert 1976). These effects on plant morphology and physiology plus other environmental influences (Laycock and Price 1970) may influence animal preference for forages during the winter.

The objective of this study was to determine differences in cattle utilization of mature tallgrass prairie and relate utilization to differences in crude protein and herbage production created by previous herbicide and fertilizer treatments.

\section{Study Area}

The study area was 2.25 ha of loamy upland rangeland, $11 \mathrm{~km}$

Authors are graduate research assistant and professor of range science. Okla homa Agricultural Experiment Station, Stillwater 74078. Baker is now range scientist at the Southern Forest Fxperiment Station, 701 Loyola, New Oreleans, La. 70113; Powell is with the Range Science Department, University of Wyoming, Laramie.

Research is a contribution of the Oklahoma Agr. Exp. Sta. as Journal Article Number 3926.

Appreciation is expressed to $\mathrm{Jim}$ Williams for providing the experimental area and cattle, to R.D. Morrison, professor of statistics, for assistance with the experimenta design and statistical analyses, and the CIBA-GEIGY Corporation for partial funding.

Manuscript received January 27, 1981. north of Stillwater, Okla. Elevation is about $280 \mathrm{~m}$. Stillwater has a continental climate with average absolute monthly maximum temperatures exceeding $40^{\circ} \mathrm{C}$ from June through September, and average absolute monthly minimum temperatures below $-20^{\circ} \mathrm{C}$ from December through March. Annual precipitation averages $820 \pm 250 \mathrm{~mm}$ and its distribution during the 210-day growing season is $21 \%$ (April-May), 28\% (June-August), and $17 \%$ (September-October). The land slope is 2 to $6 \%$ and soils are predominately fine-loamy, mixed, thermic, Udic Argiustolls (Gray and Galloway 1959). The range site is good condition loamy prairie previously used as a native hay meadow or moderately grazed by cows and calves. The major plants in the study area included Schizachyrium scoparium, Sorghastrum nutans, Panicum virgatum, Andropogon gerardi, Panicum scribnerianum, Ambrosia psilostachya, and Carex spp.

\section{Methods}

This experiment was part of a larger study designed to measure forage quality and production changes after application of atrazine, 2,4-D, and $\mathrm{N}(33-0-0), \mathrm{P}(0-45-0)$ and $\mathrm{K}(0-0-60)$ fertilizers. In 1975 a randomized block experimental design with three replications of 15 treatments was used (Table 1). All standing vegetation was mowed to a 10-cm stubble height in March, 1976, and left on the plot as ground litter. A split-plot design was superimposed on the randomized block design in 1976. One-half of each $12 \times 15 \mathrm{~m}$ plot received the same treatment as in 1975 (retreated areas), while the other half remained untreated to measure residual effects (residual areas).

Fertilizer (N, P, K) was broadcast May 10 at the rate of 67-45-45 $\mathrm{kg} /$ ha respectively. Foliar sprays of 1.1 and $3.4 \mathrm{~kg}$ a.i./ ha atrazine

Table 1. Treatment codes, treatments, and month of application for the $\mathbf{1 5}$ treatments.

\begin{tabular}{ll}
\hline \hline Treatment code & Treatment and month of application \\
\hline U & Untreated or control. \\
N & $67-0-0^{1}$ \\
NP & $67-45-0$, June. \\
NPK & $67-45-45$, June. \\
DNPK & $0.8 \mathrm{~kg} \mathrm{2,4-D/ha} \mathrm{plus} 67-45-45$, June. \\
A61 & $1.1 \mathrm{~kg}$ atrazine/ ha, June. \\
A71 & $1.1 \mathrm{~kg}$ atrazine/ha, July. \\
A63 & $3.4 \mathrm{~kg}$ atrazine/ha, June. \\
A73 & $3.4 \mathrm{~kg}$ atrazine/ha, July. \\
AN & $3.4 \mathrm{~kg}$ atrazine/ha plus $67-0-0$, June \\
ANP & $3.4 \mathrm{~kg}$ atrazine/ha plus $67-45-0$, June. \\
ANPK & $3.4 \mathrm{~kg}$ atrazine/ha plus $67-45-45$, June. \\
ADNPK & $3.4 \mathrm{~kg}$ atrazine/ ha, $0.8 \mathrm{~kg} \mathrm{2,4-D/ha} \mathrm{plus} \mathrm{67-45-45,}$ \\
& June \\
D6 & $0.8 \mathrm{~kg} \mathrm{2,4-D/ha,} \mathrm{June.}$ \\
D7 & $0.8 \mathrm{~kg} \mathrm{2,4-D/ha,} \mathrm{July.}$ \\
\hline
\end{tabular}

$167 \mathrm{~kg} \mathrm{~N} / \mathrm{ha}-0 \mathrm{~kg} \mathrm{P} 0_{5} / \mathrm{ha}-0 \mathrm{~kg} \mathrm{~K} 20 / \mathrm{ha}$. 


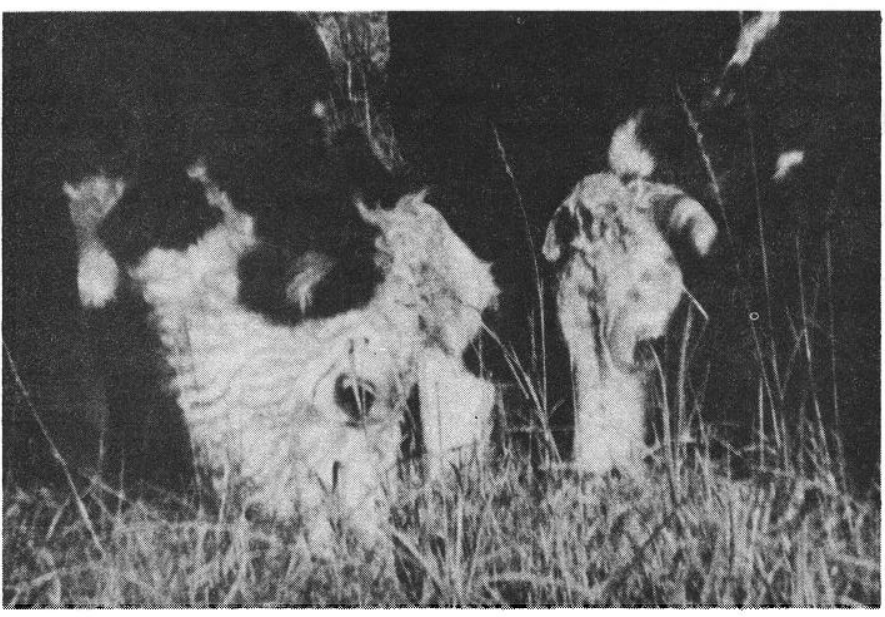

Fig. 1. Winter grazing of experimental area by nonlactating beef cows.

(2-chloro-4-(ethylamino)-6-(isopropylamino)-s-triazine) and 0.8 $\mathrm{kg}$ a.i./ ha 2,4-D, ((2,4-dichlorophenoxy) acetic acid) were applied on June 4 or July 8 .

Standing herbage biomass was estimated for each species in early November, 1976, using the modified weight-estimate (Pechanec and Pickford 1937) and double sampling methods (Wilm et al. 1944). Clipped samples were analyzed for nitrogen by the macro-Kjeldahl procedure (AOAC 1970). The area was ungrazed between March, 1975, and December, 1976.

Fifteen nonlactating beef cows freely grazed the experimental area for 18 days in December (Fig. 1). Cows were fed $0.9 \mathrm{~kg} / \mathrm{head} /$ day of $41 \%$ protein range cubes in unused areas of the enclosure. After the cows were removed, the residual herbage was determined. The difference in standing herbage before and after grazing was considered to be utilization (National Academy of Sciences 1962).

Statistically significant differences among treatments for production, grazing residue, crude protein content and utilization were tested using analysis of variance and least significant differences (Steel and Torrie 1980). The results are shown in the figure captions.

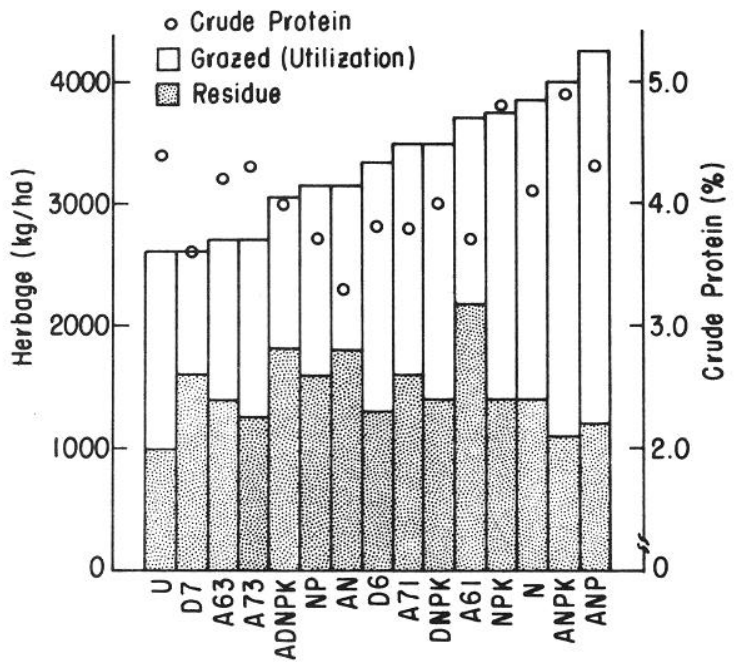

Fig. 2. Herbage production, grazing residue and crude protein content of herbage on residual areas, December, 1976. Herbage production ( $k g$ $D M / h a) \mathrm{P}<.01, L S D_{05}=800$; residue $(\mathrm{kg} \mathrm{Dm} / \mathrm{ha} \mathrm{P}<.20$; crude protein (\%) $\mathrm{P}<.28$; utilization ( $\mathrm{kg} \mathrm{DM} / \mathrm{ha}$ ) $\mathrm{P}<.02$, LSD.05=1100; utilization(\%) $\mathrm{P}<.22$.

\section{Results and Discussion}

Rainfall from May through October, 1976, was $47 \%$ of the average with no month receiving above average rainfall amounts. The previous summer (1975) was also dry and no recharge of subsoil water occurred during the $1975-76$ winter. Herbage was under water stress for much of the 1976 growing season.

Herbage production on residual areas (treated 1975, untreated 1976) in November varied from 2600 to $4300 \mathrm{~kg} /$ ha (Fig. 2). Untreated areas produced $2600 \mathrm{~kg}$ / ha while the average for treated areas was $3350 \mathrm{~kg} / \mathrm{ha}$. Herbage production on residual areas was influenced by 1975 treatments, either directly or from changes in species present (Baker et al. 1980).

Standing litter remaining after grazing on residual areas varied from 1000 to $2200 \mathrm{~kg} /$ ha with an average of $1500 \mathrm{~kg} /$ ha (Fig. 2). The four areas with the most herbage before grazing were NPK, N, ANPK, ANP, and all of these areas had less than average residue remaining after grazing. On these four areas tallgrass (Andropogon gerardi, Panicum virgatum, Sorghastrum nutans) plus Schizachyrium scoparium production was $63 \%$ (N), $71 \%$ (NPK), and $72 \%$ (ANP, ANPK) of total herbage production. The amount of residue remaining after grazing varied less among areas than did total herbage present before grazing. Utilization ranged from $38 \%$ to $72 \%$ and averaged $54 \%$ for all 15 treatments. No areas were grazed excessively. The area receiving the greatest degree of utilization $(72 \%)$ had a grazing residue of $1200 \mathrm{~kg} / \mathrm{ha}$.

The crude protein content of herbage on residual areas ranged from $3.3 \%$ to $4.9 \%$ with an average of $4.1 \%$ (Fig. 2). Crude protein content of untreated herbage was $4.4 \%$. All crude protein values were well below the protein level needed for maintenance of a mature beef cow.

Areas retreated in 1976 produced 2600 to $5200 \mathrm{~kg}$ / ha herbage (Fig. 3). Untreated areas produced only $2600 \mathrm{~kg} / \mathrm{ha}$, while the treated areas averaged $3750 \mathrm{~kg} / \mathrm{ha}$. All areas, except N-only, with above ave rage production had received a combination of fertilizers or fertilizer and herbicide. Tallgrass plus Schizachyrium scoparium production on the four treatments producing the most herbage was $62 \%$ (ANP), 70\% (NPK), 77\% (ANPK), and $81 \%$ (DNPK) of total herbage production.

The average grazing residue on retreated areas was $1200 \mathrm{~kg} / \mathrm{ha}$. Most treated areas with above average herbage production also had below average grazing residue. Utilization ranged from $43 \%$ to

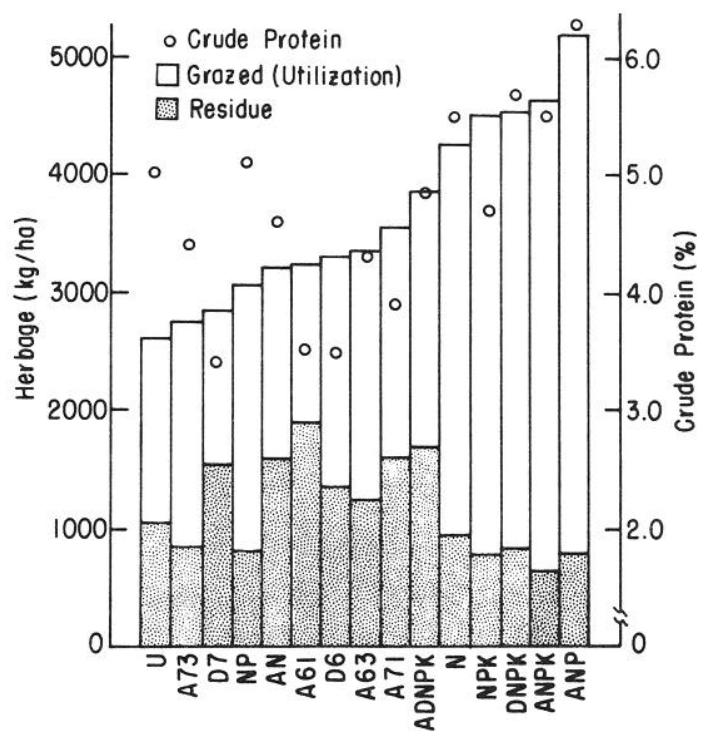

Fig. 3. Herbage production, grazing residue and crude protein content of herbage on retreated areas, December, 1976. Herbage production ( $\mathrm{kg}$ $D M / h a) \mathrm{P}<.02, L S D .05=1450$; residue ( $k g D M / h a) \mathrm{P}<.19$; crude protein (\%) $\mathrm{P}<.01, \quad L S D .05=1.5$; utilization $(\mathrm{kg} D M / \mathrm{ha}) \quad \mathrm{P}<.01$, $L S D_{.05}=1300$; utilization (\%) $\mathrm{P}<.01, L S D_{.05}=24$. 


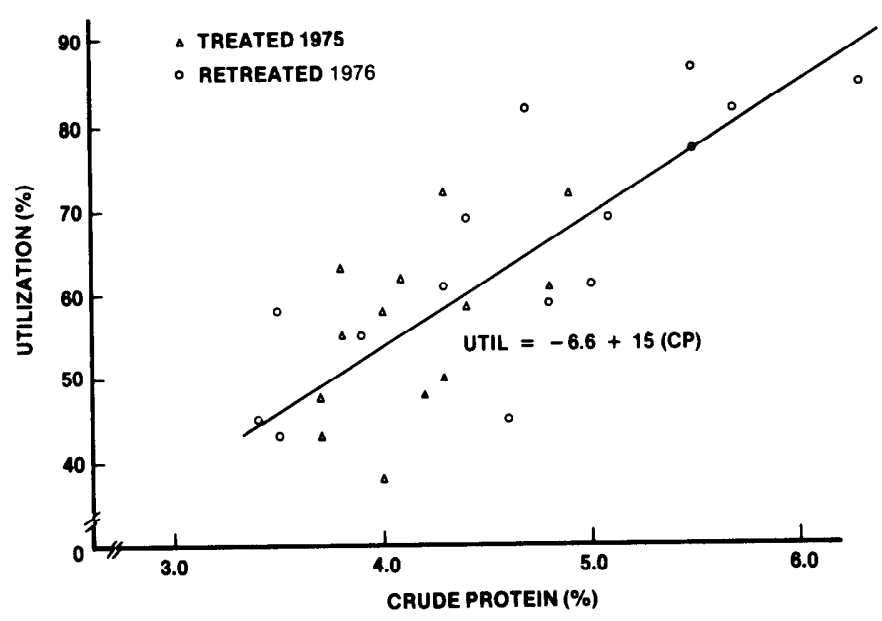

Fig. 4. Crude protein (\%) and herbage utilization (\%) relationships for 1975 treated (residual) herbage and 1976 retreated herbage.

$87 \%$ and averaged $66 \%$ on treated areas and $55 \%$ on untreated areas. Utilization on retreated areas averaged much greater than on residual areas.

The average crude protein content of herbage on all areas retreated in 1976 was $4.7 \%$ (Fig. 3), only slightly higher than on residual areas. All areas with above average herbage production also had herbage with above average protein content. All treatments with herbicide plus fertilizer, except $A N$, produced herbage with higher protein content than the average, while herbage on areas treated with only herbicide had below-average protein content.

Utilization increased as the protein content of the dormant herbage increased. For each $1 \%$ increase in crude protein content in the herbage there was a corresponding $15 \%$ increase in herbage utilization (Fig. 4). The simple linear correlation coefficient between crude protein content and utilization was $0.79(P<.01)$ using all 30 plots. There was no significant differences in regression equations for crude protein content and utilization on retreated and residual areas.

There was a $1200 \mathrm{~kg} /$ ha range between the smallest and largest residue figures for both retreated and residual herbage. A comparison of herbage utilization with crude protein and herbage production shows that cows removed nearly three times as much herbage from ANP areas as from untreated areas. Increasing herbage production did not decrease the crude protein content or utilization of cured herbage as has often been found with 2,4-D and fertilizer studies (Black and Wight 1979).

\section{Conclusions}

The addition of atrazine or 2,4-D with NP or NPK fertilizer in the spring provided a higher protein winter forage. Beef cows preferred the mature, tallgrass herbage with higher protein contents even though protein differences were small. These results are also evident in herbage treated only during the previous year.

Further study is necessary to determine longterm effects of repeated treatments of atrazine on tallgrass species' growth and quality, how treated herbage is affected by weather conditions, and the influence on preference by grazing animals. Our results indicate the proper application of atrazine and fertilizer may be used to influence grazing distribution when lightly grazed areas are fertilized for winter grazing.

\section{Literature Cited}

AOAC. 1970. Methods of analysis. IIth ed. Ass. Official Agr. Chem., Washington, D.C. 1015 p.

Baker, R.L., J. Powell, R.D. Morrison, and J.F. Stritzke. 1980. Effects of atrazine, 2,4-D, and fertilizer on Oklahoma tallgrass prairie crude protein content. J. Range Manage. 33:404-7.

Black, A.L., and J.R. Wight. 1979. Range fertilization: nitrogen and phosphorus uptake and recovery over time. J. Range Manage. 32:349-53.

Duncan, D.A., and L.O. Hylton, Jr. 1970. Effects of fertilization on quality of range forage. p. 57-62. In: Range and Wildlife Habitat and Evaluation-a Research Symposium. U.S. Dep. Agr. Forest Serv. Misc. Pub. No. 1147. 220 p.

Ebert, E. 1976. Morphology and plant growth. p. 40-48. In: F.A. Gunther and J.D. Gunther, eds. Residue Reviews, vol. 65 Effects of Triazine Herbicides on the Physiology of Plants. Springer-Verlag. New York. 103 p.

Gray, F., and H.M. Galloway. 1959. Soils in Oklahoma. Oklahoma Agr. Exp. Sta. Misc. Pub. MP-56. 65 p.

Green, L.R., K.A. Wagnon, and J.R. Bentley. 1958. Diet and grazing habits of steers on foothill range fertilized with sulfur. J. Range Manage. $11: 221-7$.

Houston, W.R., and D.H. van der Sluijs. 1975. S-triazine herbicides combined with nitrogen fertilizer for increasing protein on shortgrass range. J. Range Manage. 28:372-6.

Kay, B.L., and D.T. Torrell. 1970. Curing standing range forage with herbicides. J. Range Manage. 23:34-41.

Laycock, W.A., and D.A. Price. 1970. Environmental influences on nutritional value of forage plants. p. 37-47. In: Range and Wildlife Habitat Evaluation-a research symposium. U.S. Dep. Agr. Forest Serv. Misc. Pub. No. 1147.220 p.

National Academy of Sciences, Subcommittee on Range Research Methods. 1962. Basic problems and techniques in range research. Nat. Res. Counc., Washington, D.C. 341 p.

Pechanec, J.F., and G.D. Pickford. 1937. A weight estimate method for the determination of range or pasture production. J. Agron. 29:894-904.

Shaw, R.B., and J.D. Dodd. 1979. Cattle activities and preferences following strip application of herbicide. J. Range Manage. 32:449-52.

Shepherd, W.O., and R.H. Hughes. 1970. Supplementing range forage. p. 71-8. In: Range and wildlife habitat evaluation-a research symposium. U.S. Dep. Agr. Forest Serv. Misc. Publ. No. 1147. 220 p.

Smith, D.R., and R.L. Lang. 1958. The effect of nitrogenous fertilizers on cattle distribution on mountain range. J. Range Manage. 11:248-9.

Steel, R.G.D., and J.H. Torrie. 1980. Principles and procedures of statistics. 2nd ed. McGraw-Hill Book Co., Inc. New York. 633 p.

Wilm, H.G., D.E. Costello, and G.E. Klipple. 1944. Estimating forage yield by the double-sampling method. J. Agron. 36:194-203. 